\title{
Company Policies in Indonesia in Overcoming Employee Compensation and Job Satisfaction During the Covid-19 Pandemic Period
}

\author{
Riyan M. Faris*, Nira Aktaviana, Amdan Firmansyah, Dinda Apriliani \\ Nusa Putra University, West Java, Indonesia
}

*Corresponding author:

E-mail: riyan.mirdan@nusaputra.ac.id

\begin{abstract}
Introduction: Compensation is all benefits/results of work received by an employee for the results of his work, either directly or indirectly. Job Satisfaction is a feeling that is described as feeling happy (satisfied) with what employees get from the company. Corona or Covid-19 is a new type of virus (SARS-CoV-2). The development of the coronavirus has hit various sectors, especially the economic sector. The Covid-19 pandemic problem appears to be affecting employee compensation and job satisfaction in the workplace because employees are forced to work differently from working in offices. The purpose of the literature review is to find out how the conditions of compensation and job satisfaction of employees and companies in Indonesia during the Covid-19 pandemic. Method: Literature Review. Of the 8 studies used, 8 of them used quantitative research methods. The population is all employees in various companies and the samples used are some employees who work in companies in Indonesia and some employees of various companies in the world. Results: Based on 8 studies, it was found that Employee Compensation and Job Satisfaction from company policies during the Covid-19 Pandemic was quite decreasing. Because compensation does not significantly increase and even decreases, employee job satisfaction also decreases which can come from the extent to which people like or dislike their work. Discussion: Compensation and Job Satisfaction for employees provided by the company during the Covid-19 Pandemic is a problem that must be studied and found a solution so that employee performance remains good and quality.
\end{abstract}

Keywords: Compensation, job satisfaction, Covid-19 pandemic

\section{Introduction}

Compensation is an award given by the company to employees. An increase or decrease in employee performance can be assessed by providing compensation. Giving high compensation will spur employee morale, if the compensation is deemed unfair, the employee will feel disappointed which has an impact on employee performance. Good employees are also retained with good compensation. Compensation given motivates employee work (Kwang Chiu et al., 2002).

Every company expects its employees to provide maximum performance so that it can have a positive impact on the company. In addition to compensation, the factor that must be considered is motivation, when the company provides high motivation and compensation, each employee will provide feedback in the form of a positive influence on employee performance and the company itself.

The motivation that is owned must also be able to improve employee performance so that company goals are achieved according to targets. When company leaders can create good motivation, company leaders must be able to improve employee performance while working.

Indications of weak employee motivation are weak supervision from the company, lack of appreciation of the targets achieved, work environment such as inadequate room management so that it affects employee performance that is not optimal.

\section{How to cite:}

Faris, R. M., Aktaviana, N., Firmansyah, A., \& Apriliani, D. (2021). Company policies in Indonesia in overcoming employee compensation and job satisfaction during the covid-19 pandemic period. $1^{\text {st }}$ ICEMAC 2020: International Conference on Economics, Management, and Accounting. NST Proceedings. pages 153-162. doi: 10.11594/ nstp.2021.1018 
The employee behavior approach, an increase in the minimum wage (salary increase) will increase employee motivation in the workplace while negative events, such as employers, eliminate part of the service cost from employees. Some researchers find evidence that compensation has an impact on work motivation (Sudiardhita et al., 2018). Salary is one form of compensation and one of the main motivations in motivating work, where the goal of a person to work is to earn money to meet his standard of living. By improving the quality of good work, an employee will get an award (salary increase), so that the employee will be motivated (motivated) to continue to improve the quality of his work.

The minimum wage rate for compensation is also influenced by the geographic location of the company. If the company is located in the lowlands, drinking wages are high and compensation is high because in the lowlands the cost of living is high. Conversely, if the geographic location of the company is in the highlands, the minimum wage is small and the compensation is also small because in the highlands the cost of living is lower. A manager who has a moral responsibility will pay attention to employee job satisfaction because managers believe that if employees are satisfied they will make a positive contribution to a company.

Managers feel their efforts and performance are successful if fairness in rewards provides levels of Job Satisfaction and performance. By providing a positive and good contribution to the company, managers are responsible for employee job satisfaction. However, currently, Job Satisfaction and Employee Compensation have decreased quite low, because currently, the world economy is in decline due to the Covid-19 Pandemic. SARS-CoV-2 or Corona Virus is a virus that attacks the respiratory system. The disease caused by this viral infection is called COVID-19. The Covid-19 pandemic in Indonesia began to exist and erupted in March. So that it has an impact on the cornered economic sector. Rupiah plummeted, players in the real sector shouted to do business, and the stock market index degenerate. Economists, government authorities, and world financial institutions make alternatives or ways to predict how the economy will be during the Covid-19 Pandemic. The worst scenario could happen to the Indonesian economy if the impact of the Covid-19 Pandemic is not handled properly. Apart from destroying the capital market, the Covid pandemic has also dropped the value of the rupiah.

United States Dollar through up to Rp. 17,000. And Rp. 16,608 per US dollar is the exchange rate determined by the Jakarta Interbank Spot Dollar Rate (JISDOR). The impact was felt directly by the community as a result of the rising dollar. The US dollar currency, which is the currency for import activities, makes the price of imported imports soaring expensive. The companies affected are the pharmaceutical, fashion, electronic, textile, livestock, and steel companies/industries.

The global financial and economic crisis will affect the Indonesian economy. The expenditure and production sectors have been hit hard by the economic crisis from the impact of Covid-19. This will affect the purchasing power of the people until people's consumption decreases if the government does not immediately address it. (Head of Economy of Bank Permata Josua Pardede; 2020). Due to the economic crisis in Indonesia which resulted in a crisis in the production and expenditure sector, a company that gets profit from domestic sales, where people's purchasing power decreases and raw materials are obtained from imports, the company will be affected by the crisis. A company affected by a crisis has an impact on employee compensation. The compensation given is not appropriate because of the crisis, making employees feel unsatisfied.

The Covid-19 pandemic has caused an economic slowdown on various scales. The Indonesian Minister of Finance said the Indonesian economy would only grow by around 2.5\% to 3\% this year if this pandemic was resolved. (Layoffs) Mass layoffs will occur. If the a high potential for layoffs of employees by companies that are in trouble and the government does not anticipate that there will be massive layoffs. And four factors are the dangers of mass layoffs. Especially, companies whose production raw materials still depend on imports. secondly, the availability of raw materials is starting to run low, especially those from imports.

According to him, the industries that will be hit are labor-intensive industries, such as shoes, textiles, food, garment, beverages, electronic components, and automotive components. Because raw materials are reduced, production will decline, which will then be followed by layoffs. Third, the drop in oil prices, 
which has the potential to reduce Indonesia's income from oil exports. For the record, world crude oil prices fell to the level of US \$30 per barrel, far from the assumption of the Indonesian Crude Price (ICP) in the 2020 State Budget, which is the US \$ 63 per barrel. Fourth. The decrease in tourist arrivals to Indonesia, which directly affects job security in this industry.

Due to difficulties in maintaining their companies, many companies have laid off their employees. Employees affected by layoffs are certainly far from job satisfaction, and those who are not affected by layoffs also decrease Job Satisfaction and Compensation. As well as shortened working hours, the absence of overtime hours, and mobile companies that find it difficult to reduce wages. This shrinking salary has decreased the job satisfaction of employees, but due to this pandemic, many employees remain in their jobs, so the premise is that a worker (employee) will stay in his job and improve his job even though it is difficult to survive. But that's better than employees who were deeply dissatisfied with layoffs.

Another impact on employees who are still working according to government policies that implement PSBB. With this large-scale social application, companies are implementing the Work From Home (WFH) work system. WFH or also known as remote working are people who work in a place other than their workspace in the office. WFH is a step or policy taken by the government to suppress the Covid19 Pandemic, but company productivity continues to run. Despite implementing the WFH policy of working at home, operational productivity continues. With WFH the motivation of the employees will decrease. The reasons are quite diverse, for example, the atmosphere at home is not like an office, the work atmosphere is not as expected (Al-Omari \& Okasheh, 2017).

An effective Work from Home (WFH) policy can be implemented by establishing a Clear Work From Home (WFH) Procedure. A clear WFH procedure is intended so that employees can continue to work productively in their homes. The contents of the WFH procedures are clear, systematic, and structured work desks regarding daily working hours, employees must submit their work. A clear work from the home procedure will motivate employees to work. So, with this policy, the company can carry out its corporate activities, in this pandemic situation. WFH is indeed proven in its effectiveness as a remote company, but it has received positive responses and job satisfaction from employees.

\section{Material and Methods}

This discussion with the author looking for journals using a literature review. International-based journal literature reviews can be accessed through www.sciencedirect.com By typing the keyword "Compensation and job satisfaction" came 13,377 findings. Then typing the keywords "Covid-19 Pandemic, Job Satisfaction, Compensation" appeared 55 findings, plus typing the keyword "job satisfaction and the coronavirus" appeared 77 findings. Sort out the suitable journals for making this journal. The language selection was not carried out because the international journal was based in English. With the scope of the state of the company, its policies regarding job satisfaction and compensation, and employees' responses to company policies.

Methodology To measure job satisfaction, the Minnesota Satisfaction Questionnaire is used. One of the most commonly used instruments in measuring job satisfaction is called the Minnesota Satisfaction Questionnaire (MSQ). This is a methodology for measuring job satisfaction in various sectors. The short MSQ consists of twenty aspects, each of which is represented by only one satisfaction item. The short form MSQ measures three satisfaction scales, namely intrinsic satisfaction, extrinsic satisfaction, and overall job satisfaction. Intrinsic satisfaction refers to job conditions and extrinsic satisfaction refers to environmental conditions. To measure tested compensation from questionnaire data that includes evaluation of the position of each employee in various companies and various fields.

With a method that focuses on in-depth observation in 8 (eight) selected journals, it is studied with the contents of the theory of experts and in-depth analysis of employee compensation and job satisfaction and company policies in Indonesia during the Covid-19 Pandemic. 


\section{Results and Discussion \\ Emphasis on job satisfaction, employee compensation, and company policies}

The quest to understand job satisfaction and/or dissatisfaction is an area of continuing interest for social scientists and managers. The premise is that satisfied workers will be more productive and stay with the organization longer, whereas they tend to quit because dissatisfied employees will be less productive. Understanding Job Satisfaction is not just a theoretical exercise, making it possible to structure and conduct more effective responses to job satisfaction or dissatisfaction; specific responses targeted specifically at contributing factors at the individual, organizational level.

The first studies of job satisfaction began in 1935 with Hoppack. Research over 70 years of research is a clear indication of the need to have a clear understanding of attitudes towards work and how these attitudes have a strong effect on various aspects related to organizational behavior. definition of job satisfaction as a person's reaction to his job. or organization. In general, it is said that job satisfaction is a reaction to employees resulting from a comparison of a person's actual results with what he wants, is anticipated, or deserves (Rafferty \& Griffin, 2008).

According to the data, a job is generally happiest with their area of responsibility (the desired part/work environment), the organization they work for, their relationships with colleagues and direct subordinates, and the joy and meaning that comes from them.

Unsurprisingly, occupations with senior income levels earn more than workers with less senior degrees. The work environment is currently undergoing major changes; Factors such as globalization, economic growth, and technological improvements constantly present new challenges and create new opportunities for humans. Our work is not only a main source of income but also an important part of our life which contributes to our social status.

Dissatisfaction among human resources is undesirable and dangerous in any profession. Satisfied and committed human resources are the most significant asset of any organization, including banks and because banking institutions are the backbone of a country's economy, efficient management of human resources and a higher increase in job satisfaction affects overall growth and performance. Poor environmental conditions at work are negatively related to job satisfaction.

In total, the magnitude of this effect is proportional to other important matters such as changes in compensation and employment. Regarding the former, while the absolute income level is not significant it cannot explain satisfaction ob, change of salary. Apart from environmental conditions, perceptions of occupational health or safety risks have a negative relationship with job satisfaction.

The dependent variable in the empirical estimate, Job satisfaction comes from the answer to the job satisfaction question (Overall, are you very satisfied, satisfied, not very satisfied or completely dissatisfied with the working conditions at your job?). With an average job satisfaction response of 3.093, workers in the sample report are "satisfied". Most respondents are either satisfied (58.8\%) or very satisfied (25\%) with their job, although there are important cross-national differences. people in Denmark, Norway, Austria, Switzerland, Great Britain, and Ireland, on average, are happiest at their jobs while Eastern European workers are the least satisfied.

The finding of salary as the main motivating factor was corroborated by other researchers who found that employees place a good salary as the main driving factor. The discovery of salary as the main motivation has become commonplace for employees or workers. This finding is evidenced by the presence of a sample of several employees who negotiate wages with their companies, if this is not fulfilled then the employees will look for the appropriate company, this is adjusted to their expertise, the company needs their expertise, and employees need something equivalent. salary. This finding occurred with a percentage of $44 \%$ of the sample of employees in the Indonesian region, to be precise in West Java. The motivation and reward factors found by supervisors were the highest, followed by good wages and good working conditions. Based on previous research work motivation to enter is influenced by employee satisfaction with compensation (Sudiardhita et al., 2018).

Compensation and job satisfaction are currently hard to feel because of the difficulty of the economy during this Pandemic. The COVID-19 pandemic will have an impact on various aspects such as politics, 
economy, social, culture, defense, and security as well as the welfare of the Indonesian people following Government Regulation No. 21 of 2020. The existence of this PSBB has made the government urge companies to work from home or work from home. (WFH) as a measure used to support the implementation of social distancing programs designed by the government. Because of the Covid-19 outbreak, the PSBB policy was made. This piracy has an impact on conditions that compel companies to undertake WFH. The WFH can affect various aspects of work, one of which is job satisfaction.

With the running of WFH, some employees feel job dissatisfaction for several reasons, this is based on an analysis of several professions in Indonesia, namely: First, the reasons for lack of rest and increased work represent indicators of ability. Before the Covid-19 Pandemic, these professionals used to carry out their daily routine at work.

However, after/during the Covid-19 Pandemic, they were forced to work differently. Certain professions must continue to work outside working hours (for example, health and security personnel) so that they do not get adequate rest, even though the work increases/increases. As a result of the increase in work, the work was not completed effectively. The two reasons are the difficulty of carrying out activities and there are limitations in social interactions that describe indicators of the work environment. With the existence of Covid-19, activities that were originally normal had a bad impact so that many workers complained about the difficulty of interacting properly with colleagues and other communities. Although they can communicate using media technology, direct communication and using media are less flexible. The three reasons for undisturbed and unfocused work reach represent indicators of creativity. So that many workers take issue with this because it is very influential both in the reach of work and control so that it affects the ideas of the employees/workers.

The WFH can provide flexible working hours for employees so that the work they do can be completed easily. However, the flexibility of working hours for WFH employees often causes other things such as increased working hours. This is supported by research on work from home in the US, UK, Canada, and New Zealand which found that flexibility can exacerbate excessive work and even increase occupational dominance (Davidescu et al., 2020).

Based on a preliminary study conducted on several employees who perform WFH, it is known that the working time during WFH becomes longer when working in the office. Not only in Indonesia, but employee working hours in the United States have also increased by an average of 3 hours since the implementation of WFH, while in England, France, Spain, and Canada it has increased by 2 hours. So, the premise is when WFH Employee Satisfaction has a satisfied and dissatisfied side. Job Satisfaction refers to more flexible working hours, but the work uncertainty that comes from increasing more working time while working at the office.

The shows that employees with high emotional intelligence will have high job satisfaction as well. Employees who have high emotional intelligence tend to have positive emotions so that they can be satisfied with their work because they work in jobs and direct their emotions in various situations, especially when doing WFH in the middle of a pandemic. The ability in emotional intelligence to solve problems, be socially responsible, and talk about abilities that are directly related to how someone helps conflict in the workplace and can affect job satisfaction of employees who have to do WFH.

\section{Discussion}

Compensation satisfaction is a general evaluation of satisfaction with salary levels, salaries, and administrative salaries (Prasetio et al., 2019). Decisions about the compensation system for employee compensation satisfaction. Therefore, employers must design an effective compensation system because compensation affects employee work behavior. With high compensation becomes someone's race to improve the quality of work, it is different if employees are not satisfied with the compensation system in their company, the quality of performance is difficult to improve. So, it becomes important for companies to create a compensation system that can satisfy employees so that the quality of their performance increases, with the quality of performance, a company can achieve its company goals.

Compensation is provided in the form of, such as bonuses, allowances, and salaries. Salary is the result of an employee's work in the form of money, the work result of his contribution to the company. 
The premise is that salary has a positive effect on employee performance. With compensation that is appropriate to the level of work and is good and appropriate, it will increase employee income, Knowing that the poverty rate can increase employee income. Awareness about the part the compensation system is integral as employers' decisions about then the compensation system can affect employee satisfaction with compensation and work behavior (Association of Malaysian Hotels (MAH, 2013a, b). From that with an increase in the income of workers (employees) from an increase in compensation using a significant increase in the minimum wage continuously will improve the quality of life, increased purchasing power thereby increasing the economic activity of a nation.

Examined the role of compensation in university employees' work motivation and found that motivation can be relied on by salary, promotion, recognition, working conditions, and benefits. A living wage is sufficient to cover more than just basic needs and also enable people to have a minimum acceptable standard of living. Therefore, it is important to understand the extent to which minimum wage policies have improved the standard of living of employees, given the possible increase in the cost of living. Living wages allow one to have a decent standard of living.

Where the standard of living will continue to advance or increase over time, therefore a decent wage gets the results of one's performance by feeling job satisfaction and being given proper compensation.

The employee reward system must be based on the type of work performed, the level of skills and knowledge, as well as the responsibilities, carried so that employees work and are motivated towards their work so that they meet the "compensation" aspect of their work.

Performance-based bonuses and human resource policies such as open communication, career development programs, and reward systems have contributed to human resource retention. Allowances are an additional stage from the company to employees. The positive significance for employee performance is hampered by benefits. While the bonus is another word of incentive compensation. Bonuses obtained from good and better performance results are also a company way to motivate employee performance.

The performance means quality and quantity work results that can be achieved by an employee in carrying out his duties according to the responsibilities assigned to him. In a company, one important factor is the leader. Good employee performance also comes from good leadership. Lead messages, organize, plan and organize these various organizations.

From a public policy point of view, since work is such a fundamental part of people's lives, understanding job satisfaction is seen as an integral part of understanding overall life satisfaction and the wellbeing of society. Indeed, job measures and life satisfaction are positively correlated, and their constructs appear to be interrelated and influence each other. Wage (Salary (Compensation)) is an important determinant of job satisfaction. Job satisfaction has been defined in a number of ways, with the definition being the most commonly used in the literature.

The motivation process is the satisfaction of job satisfaction, the results and performance of the imbalances and disagreements they receive and the rewards for employee satisfaction in the company. The premise is that the level of job satisfaction is indicated by results such as absenteeism or absenteeism, attitudes of organizational members, organizations, and organizational changes that occur within an organization. It can be seen and measured clearly how an employee feels job satisfaction in a company that sees his attitudes and actions at work. The job satisfaction of an employee will be seen by his loyalty to the company and his work, the employee's dissatisfaction with the sense of loyalty will decrease, always thinking about absenteeism or absenteeism.

Employees' views of their work, whether they serve or not, are a reflection of job satisfaction. Job Satisfaction of an employee will increase if it is in line with his preferred conditions, such as conditions for fulfilling facilities, working according to his interests, and conditions of appropriate compensation. The level of job satisfaction is also measured by the placement of job placements (high positions) compared to employees with low job placements, high positions show that employees are more active in expressing ideas, are more active and better working abilities, and always find ways to be creative and innovative at work. When asked why they chose to stay at their current job, the top response (44\%) was, 
"I find joy and meaning in my job." By finding rewards, a salary increase a salary fit, job satisfaction) and meaning in work, a worker who is happier with his job may be more productive and earn more.

The six main sources of Job dissatisfaction are responsibility, independence, policies and practices, compensation, and diversity indicating bank authorities that steps need to be taken to develop and implement human resource management policies towards improving undesirable conditions and strengthening desired conditions. For example, training and development programs could be developed to enhance the skills and knowledge of employees and enrich their work, contribute to the (variation) facet of the job and help develop pathways for those that contribute to the "progress" satisfaction of their jobs. Employee training programs are significant in improving and developing the level of service an organization provides because of the skills of employees which ultimately increase customer satisfaction quoted from Khan et.al., 2011).

Of the six main sources of Job Dissatisfaction, three of which are Progress, Compensation, policies, and practices, are things that are currently happening uncertain. The current condition is where Indonesia is also experiencing a global economic crisis due to the impact of the Covid-19 Pandemic. China, which became the first country to be confirmed by Covid-19, is slowly cornering the Indonesian economy. Then followed by countries including Indonesia which confirmed that they were also affected by Covid19. The progress of the company is slow and quite difficult due to the global economic crisis, the government for the crisis of the development of Covid-19 by implementing the PSBB (Large-scale Social Restrictions) and the practices of the PSBB also implementing WFH (Work from Home), also affects the compensation of employees who also decrease to maintain the company.

To maintain other than the company by reducing compensation, the company also laid off some of its employees. The fact that this pandemic has an impact on the economy cannot be avoided because several companies have begun to go bankrupt which has resulted in cuts in wages and even layoffs. Based on data from the Ministry of Manpower as of April 20, 2020 there were 2,084,593 workers from 116,370 companies laid off and laid off due to the impact of the Covid-19 Pandemic.

One of the problems that need to be evaluated is employee job satisfaction. The satisfaction appears can come from internal employees or external employees. Satisfaction arises from internal relationships with personality traits. A positive personality usually will not blame external conditions, so that employees feel satisfied that it is part of their feelings. The satisfaction that arises externally is due to external causes that do not feel comfortable working. One of the external conditions that arise and disturb employees can serve the Covid-19 pandemic phenomenon.

As a result of the Covid-19 Pandemic, employees have to work at home (WFH). Some employees feel that they are not satisfied enough when they have to work at home, because of the different atmosphere and facilities that support work. However, for some employees who feel satisfied because they prefer to work at home by working at home, they are more relaxed at work because they are not directly monitored by the leadership, working hours become flexible, and can enjoy longer togetherness with their families. This condition is in the workplace, always monitoring and working hours are more stringent.

In general, compensation for employees who usually work in an office can improve life balance and psychological well-being so that they expect big when doing WFH can affect these things. However, a study of WFH workers in the UK did not find a relationship between workers who worked with WFH about family-work conflicts. The extracts can also create stress by blurring the boundaries of the balance because it causes too much work or problems. Therefore, flexibility in working when WFH can be one of the obstacles in one's job. Smoke in work, based on the preliminary study conducted, it turns out that there is still something related to employees when doing WFH. Adjusting to the conditions of the work environment at home makes some employees feel difficult because of the lack of available facilities such as the internet and some jobs that cannot be done at home. The found in their research that work facilities can affect employee job satisfaction.

Implementing WFH amidst a successful and successful roadway pleasant working conditions for employees. Uncertainty about when the pandemic will end as well as various news such as salary cuts, 
holiday allowances (THR) to layoffs at several companies makes employees who carry out WFH feel restless and unsatisfied with their work.

Although there are several companies that no longer have WFH, various reports about cuts in wages and cuts in benefits are still troubling employees. Amid a crisis that has an impact on the economy, where various companies are competing to keep their expenses, such as employee payments and benefits, are also the last choice for companies. This can make employee job satisfaction decrease and also allow it to have an impact on other things. Another impact is reducing work motivation on employees.

Apart from cutting wages and benefits they also miss many opportunities to develop their careers. Participating in training programs and opportunities for promotion due to an indefinite period due to the impact of this pandemic. This is for those who can reduce employee job satisfaction because in studies related to the opportunity to participate in training programs can increase job satisfaction (Schmidt, 2007). Many obstacles occur by employees while doing WFH. Someone who has emotional intelligence can certainly find it easier to deal with these obstacles. The results of this research show that emotional intelligence creates job satisfaction. In line with this, related research has found that emotional intelligence has a significant relationship with conflict management styles.

Not only employees who have emotional intelligence, a leader is also required to have emotional intelligence. because in times of crisis like this a leader must be a wise example for other employees in facing various problems during WFH and also when facing other things during this pandemic that make their productivity decrease. In a study, on 92 participants from two levels who were middle-level organizational leaders and lower-level employees in an electric power industry company in South Africa 8. The results of this study indicate that there is a significant relationship between the emotional intelligence of leaders and employee job satisfaction. This shows that a leader with high intelligence, the job satisfaction of other employees will be high too. In line with this research, a leader who has high emotional intelligence influences employee job satisfaction, employee psychology, employee performance both individually and in groups, and customer satisfaction (Omah \& Obiekwe, 2019).

Table 1. The lists of respondents

\begin{tabular}{|c|c|c|c|c|}
\hline No. & Author / Title & Respondents & $\begin{array}{l}\text { Assessment } \\
\text { Procedure }\end{array}$ & Result \\
\hline 1. & $\begin{array}{l}\text { Björn Gunnar } \\
\text { Hansena, Egil Pet- } \\
\text { ter Stræte / Dairy } \\
\text { farmers' job satis- } \\
\text { faction and the in- } \\
\text { fluence of auto- } \\
\text { matic milking sys- } \\
\text { tems (Hansena et } \\
\text { al., 2020). }\end{array}$ & $\begin{array}{l}\text { The number of } \\
\text { samples is } 1288 \\
\text { people with total } \\
\text { sampling tech- } \\
\text { nique who } \\
\text { work as dairy } \\
\text { farmers. }\end{array}$ & $\begin{array}{l}\text { The analysis in this } \\
\text { study uses a quanti- } \\
\text { tative study and then } \\
\text { this study also uses } \\
\text { the } \\
\text { Respond- } \\
\text { ing to } \\
\text { Questionnaires } \\
\text { which are managed } \\
\text { by the web } \\
\text { ence with refer- } \\
\text { to Automatic } \\
\text { tems (AMS) and } \\
\text { Conventional Milk- } \\
\text { ing Systems } \\
\text { (CMS). }\end{array}$ & $\begin{array}{l}\text { The results showed that AMS } \\
\text { farmers experienced higher } \\
\text { satisfaction with working } \\
\text { days, work safety and work } \\
\text { environment than CMS farm- } \\
\text { ers. And influenced by in- } \\
\text { creased income, new cow- } \\
\text { shed, successors, continued } \\
\text { farming. }\end{array}$ \\
\hline
\end{tabular}

To be continued... 


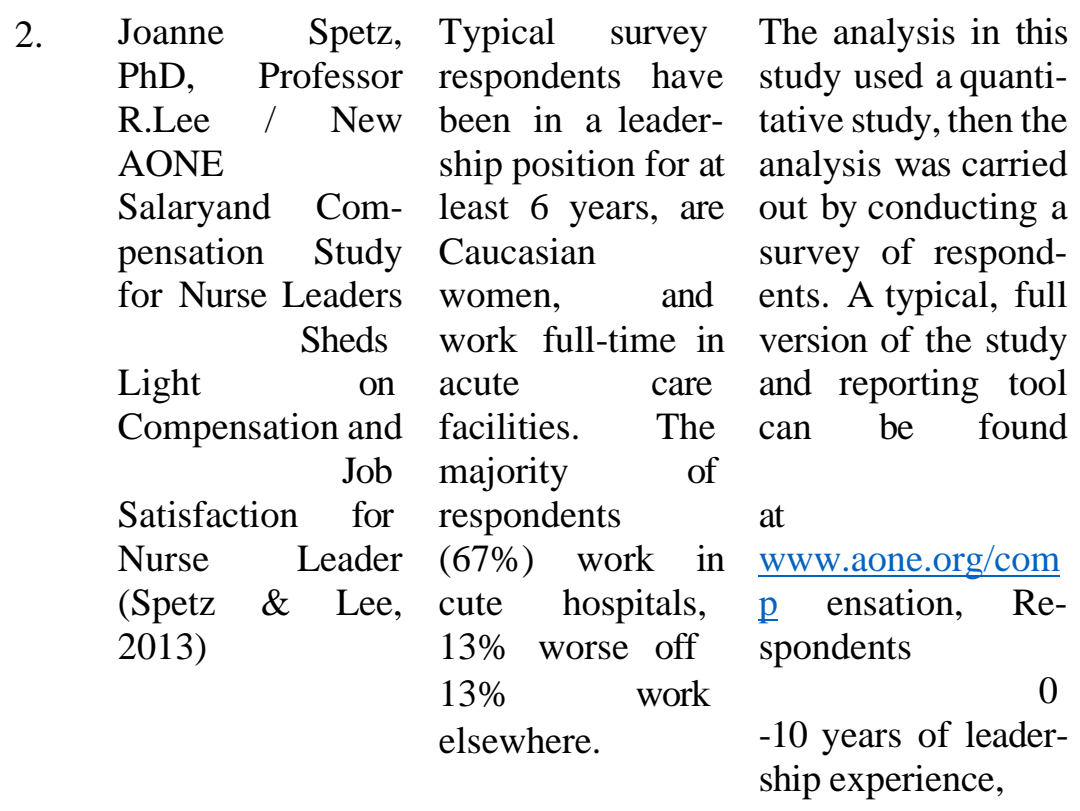

The results showed that continuing to develop and hone skills to improve the quality of workers, nurse leaders had higher salaries than the national average. Nurse leaders are more satisfied with their job, than their compensation. because while working the nurses find happiness in their work.

ship experience,

\section{Conclusion and Recommendations}

From 8 studies, it was described that Compensation and Job Satisfaction of employees and company policies in Indonesia during the Covid-19 Pandemic were low. The Covid-19 pandemic, which has an impact on the global economic crisis and human resource crisis, has made it difficult for several companies to maintain their companies. And because during the Covid-19 Pandemic, the government issued a Large-Scale Social Restriction (PSBB) policy which resulted in companies having to implement PSBB policies and in practice using the Work from Home (WFH) system. From several analyzes and research, it shows that WFH can show Job Satisfaction. Because during the Covid-19 Pandemic, the economic crisis made corporate banks compete to defend their companies, there were many ways to maintain their companies, including cutting wages, cutting benefits, even no allowances, laying off employees, not providing training to provide promotions, making satisfaction Downhill work. Salary as a form of compensation that motivates and becomes a race for employees as well as a measure of job satisfaction, if the salary is not appropriate (there is a cut) then work motivation will decrease in line with uncertainty.

Company leaders and employees must support each other and work for hand in hand to improve the company again so that it also impacts on good and appropriate compensation to make employees feel job satisfaction. By increasing good emotional intelligence by company leaders and employees in facing the conditions of the Covid-19 Pandemic. Based on research and analysis, someone who has high emotional intelligence can increase job satisfaction.

\section{References}

Ahmat, N. H. C., Arendt, S. W., \& Russell, D. W. (2019). Effects of minimum wage policy implementation: Compensation, work behaviors, and quality of life. International Journal of Hospitality Management, 81, 229-238.

Al-Omari, K., \& Okasheh, H. (2017). The influence of work environment on job performance: A case study of engineering company in Jordan. International Journal of Applied Engineering Research, 12(24), 15544-15550.

Bhardwaj, A., Mishra, S., \& Jain, T. K. (2020). An analysis to understanding the job satisfaction of employees in banking industry. Materials Today: Proceddings, 2214- 7853. https://doi.org/10.1016/j.matpr.2020.04.783

Davidscu, A. A., Apostu, S-A., Paul A., \& Casuneanu, I. (2020). Work Flexibility, Job Satisfaction, and Job Performance among Romanian Employees-Implications for Sustainable Human Resource Management. Sustainability, 12, 6068. doi:10.3390/su12156086

Erro-Garces, A., \& Ferreira, S. (2019). Do better workplace environmental conditions improve job satisfaction?. Journal of Cleaner Production, 219, 936-948. 
García-Rodríguez, F. J., Dorta-Afonso, D., \& Rosa, M. G. (2020). Hospitality diversity management and job satisfaction: The mediating role of organizational commitment across individual differences. International Journal of Hospitality Management, 91, 102698.

Hansena, B. G., \& Stræteb, E. P. (2020). Dairy farmers' job satisfaction and the influence of automatic milking systems. NJAS - Wageningen Journal of Life Sciences, 92, 100328.

Kwan Chiu, R. K., Luk, W. W-M., \& Tang, T. L-P. (2002). Retaining and motivating employees: Compensation preferences in Hong Kong and China. Personnel Review, 31(4), 402-431. DOI:10.1108/00483480210430346

Omah, O., \& Obiekwe, O. (2019). Impact of employee job satisfaction on organizational performance. International Journal of Current Research, 6(12), 2343-403.

Prasetio, A. P., Agathanisa, C., \& Luturlean, B. S. (2019). Examining Employee's Compensation Satisfaction and Work Stress in A Retail Company and Its Effect to Increase Employee Job Satisfaction. International Journal of Human Resource Studies, 9(2), 239. DOI:10.5296/ijhrs.v9i2.14791

Rafferly, A. E., \& Griffin, M. A. (2008). Job satisfaction in organizational research. BUCHANAN:The SAGE Handbook of Organizational Research Methods. 196-212.

Saner, T., \& Eyupoglu, S. Z. (2009). The relationship between job satisfaction and academic rank: a study of academicians in Northern Cyprus. Procedia - Social and Behavioral Sciences, 1(1), 686-691.

Schmidt, S. W. (2007). The Relationship between Satisfaction with Workplace Training and Overall Job Satisfaction. Human Resource Development Quarterly, 18(4), 481 - 498. DOI:10.1002/hrdq.1216

Spetz, J., \& Lee, R. (2013). New AONE salaryand compensation study for nurse leader sheds light on compensation and job satisfaction for nurse leader. Nurse Leader, 11(5), 21-25.

Stamolampros, P., Korfiatisb, N., Chalvatzis, K., \& Buhalis, D. (2019). Job satisfaction and employee turnover determinants in high contact services: Insights from Employees’Online reviews. Tourism Management, 75, 130-147.

Sudiardhita, K. I. R., Mukhtar, S., Hartono, B., Herlitah, H., Sariwulan, T., NIken, S. I. (2018). The effect of compensation, motivation of employee and work satisfaction to employee performance Pt. Bank xyz (Persero) TBK. Acedemy of Strategic Management Journal, $17(4), 1-10$. 